\title{
A Norm Study of a Neuropsychological Test Battery for Evaluating Cognitive Functions in Commercial Airline Pilots
}

\section{Zehra Ozdil Arikan ${ }^{10}$, Dijan Ertemir'車 Cahit Keskinkilic ${ }^{20}$}

'Health Directorate of Turkish Airlines, Istanbul - Turkey ${ }^{2}$ Bakirkoy Research and Training Hospital for Psychiatric and Neurological Diseases, Department of Neuropsychology, Istanbul - Turkey

\section{ABSTRACT}

A norm study of a neuropsychological test battery for evaluating cognitive functions in commercial airline pilots

Objective: This study aims to establish a norm for Turkish commercial airline pilots with a neuropsychological test battery that has been prepared specifically for pilots. The test battery assesses all of the attention components that are critical for piloting: working memory, information processing rate, mental flexibility, reaction time, set switching, inhibiting cognitive interference, several parameters of short/long term visual memory, and spatial comprehension.

Method: The study included 147 healthy commercial airline pilots, of whom 144 were men and 3 women. The participants were divided into four age groups: 20-29 years, 30-39 years, 40-49 years, and 50 years and above. They were given the following tests: Wechsler Adult Intelligence Scale-Revised (WAIS-R) Digit Span, Rey Complex Figure Test (RCFT), Continuous Performance Test (CPT), Paced Auditory Serial Addition Test (PASAT), Reaction Time Test (RTT), d2 Test of Attention (d2TA), Stroop Test (ST), Trail Making Test (TMT), Visual Elevator Test (VET), and Judgement of Line Orientation Test (JLO).

Results: There was a relation between age and military vs. civilian background, type of bachelor's degree, and flight experience, but no relation was found between age and hand dominance. It was found that there was a significant difference in all test scores between age groups except for CPT scores, d2 Test percentage of errors and total number of errors, ST $1^{\text {st }}, 2^{\text {nd }}, 5^{\text {th }}$ card self-corrections and $3^{\text {rd }}$ card errors, TMT A and B Form errors, and VET switching numbers.

Conclusion: It was concluded that commercial airline pilots' neuropsychological test scores differ according to age but not by hand dominance. The importance of pilot norms and the necessity of comparing pilots according to professional norms was highlighted in the discussion.

Keywords: Attention, memory, neuropsychological tests, norm, pilots

\section{öz}

Ticari havayolu pilotlarında bilişsel işlevleri değerlendirmek için oluşturulmuş bir nöropsikolojik test bataryası norm çalışması

Amaç: Bu çalışmada pilotlara özgü bir nöropsikolojik test bataryası hazırlanarak, batarya dahilindeki testlerin ticari havayolu şirketlerindeki Türk pilotlar için normlarını oluşturmak amaçlanmıştır. Test bataryası pilotaj için önemli olan; dikkatin tüm bileşenlerini, çalışma belleğini, bilgi işlemleme hızını, zihinsel esnekliği, reaksiyon zamanını, set değiştirebilmeyi, uygunsuz cevap eğilimini bastırabilmeyi, kısa/ uzun süreli görsel belleğin çeşitli parametrelerini ve uzaysal algılama yetilerini değerlendirmektedir.

Yöntem: Çalışmaya ticari bir havayolu şirketinde görev yapan 144'ü erkek, 3'ü kadın olmak üzere 147 pilot katılmıştır. Katııımcılar 20-29, 30-39, 40-49 ve 50 üstü olmak üzere dört yaş grubuna ayrıımıştır. Katııımcılara şu testler uygulanmıştır: WAIS-R Sayı Dizisi Testi, Rey Karmaşık Figür Testi (RKFT), Sürekli Performans Testi (SPT), PASAT Test, Tepki Süresi Testi (TST), d2 Dikkat Testi (d2DT), Stroop Testi (ST), İ Sürme Testi (IST), Asansör Testi (AT) ve Çizgilerin Yönünü Belirleme Testi (ÇYBT).

Bulgular: Yaş ile asker-sivil kökenli olma, lisans eğitimi ve uçuş tecrübesi değişkenleri ilişkili bulunurken, el baskınlığı değişkeni ilişkili bulunmamıştır. Yaşa göre nöropsikolojik testler değerlendirildiğinde; SPT puanları, d2 Testi hata dağıımı ve hata toplamı, ST 1. 2. 5. kart düzeltme sayısı ve 3. kart hata sayısı, iST A ve B Formu hata sayısı ve AT değiştirme sayısı puanları dışında tüm test puanlarında anlamlı farkllık olduğu saptanmıştır.

Sonuç: Ticari havayolu pilotlarındaki ortalama nöropsikolojik test puanlarının yaştan etkilendiği, el baskını̆̆ına göre ise farklılık göstermediği tespit edilmiştir. Pilot normlarının önemi ve kendi meslek normlarına göre değerlendirilmesi gerekliliği tartışma bölümünde ele alınmıştır.

Anahtar kelimeler: Dikkat, bellek, nöropsikolojik test, norm, pilotlar

How to cite this article: Ozdil-Arikan Z, Ertemir D, Keskinkilic C. A norm study of a neuropsychological test battery for evaluating cognitive functions in commercial airline pilots. Dusunen Adam The Journal of Psychiatry and Neurological Sciences 2018:31:375-388.

https://doi.org/10.5350/DAJPN2018310406

Address reprint requests to / Yazıșma adresi: Zehra Ozdil Arikan

Health Directorate of Turkish Airlines, Yenibosna Merkez Mahallesi, Cinar Caddesi, No: 6, Bahcelievler/Istanbul, Turkey Phone / Telefon: +90-212-463-6363/12352

E-mail address / Elektronik posta adresi: zehraozdil@gmail.com

Date of receipt / Geliş tarihi: September 5, 2017 / 5 Eylül 2017

Date of the first revision letter / Illk düzeltme öneri tarihi: October 12, 2017 / 12 Ekim 2017

Date of acceptance / Kabul tarihi: May 14, 2018 / 14 Mayıs 2018 


\section{INTRODUCTION}

$\mathrm{N}$ europsychology is a discipline developed on the basis of the relation between brain and behavior (1). Neuropsychological assessment is an approach examining the effect of brain-related diseases with mental processes and behaviors, using psychometric tests to perform the necessary measurements. Neuropsychological tests allow for an objective measurement of mental functions. They are frequently used for clinical diagnoses, in the follow-up of patients, and in the evaluation of therapy and rehabilitation (2). Within a given society, the behavior of the majority of people belonging to the same age range, level of education, and gender defines what is "normal." Assessing ill persons is possible in comparison with the normal values. Therefore, it is important to use tests for which the "normal" values are known and standardization studies have been carried out (1).

The profession of pilots is an occupation where human errors are particularly costly and can lead to deadly results (3). For flight security and failsafe aviation operations, the selection of pilots and air controllers is of great importance; for this reason, during the recruiting process a number of neuropsychological tests are applied in addition to a psychiatric examination and various psychological tests (4). The measurement of cognitive functions is used not only to select competent people to become pilots, but they are also applied to screen for certain diseases and monitor the state of health (5). After suffering a head trauma or a disease that affects mental capacities, aviators have to undergo a neuropsychological evaluation before returning to flying. However, the majority of standard neuropsychological tests use norms for the general population. As aviators are a particular group, it is necessary to compare test performances among members of this group $(6,4)$. There are differences even between individual pilots. It is not recommended to apply the same test battery to different professional groups. For example, in a study comparing trainee astronauts with trainee pilots, it was found that in pilots memory, speed of perception, and spatial perception were more developed, while astronauts were more successful in technical understanding and mental arithmetic (3).

Considering the organizational and social costs and risks involved, choosing pilots carefully is of particular importance (7). Various test batteries are used in the neuropsychological assessment of pilots, among them the DLR test designed by the Deutsches Zentrum für Luft- und Raumfahrt - German Aerospace Center (DLR), FAA (Federal Aviation Administration)'s Cogscreen AE (Aeromedical Edition), CogState, which is used in Australia, or the Vienna Test Battery. All of these tests are carried out on the computer; generally, they measure concentration, auditory and visual shortterm memory, sense of space, psychomotor coordination, and multitasking capacity.

The following conditions are frequently encountered in aviation neuropsychology: head trauma, alcoholism and substance addiction, dementia and slight cognitive disorder, AIDS, attention deficit/ hyperactivity disorder, and depression. In addition, it is important to assess pilots with performance problems neuropsychologically (8).

Knowledge of brain structure is required to understand which functions the tests included in a battery measure. Different cognitive processes in the human brain are running in the right and left hemisphere, respectively. The localization of basic cognitive functions in different hemispheres is defined as brain asymmetry (or lateralization). The left hemisphere is in charge of mathematical processes, interpretation of numerical symbols, logical thought, as well as reading and writing, speaking, understanding, and verbal functions including verbal memory. The right hemisphere is dealing with functions that cannot be verbalized, such as configurational processing, acquisition and storage of visual data, visual and haptic recognition of patterns and forms, visual orientation and perception of perspective, and the drawing and copying of geometric patterns and images $(9,10)$. Hand dominance is the most conspicuous characteristic of lateralization. Persons with right-brain dominance tend to have a dominant left hand, those with a dominant left brain the reverse. 
Important for the profession of pilot are attention parameters, short-term and working memory. In aviation, conscious control and direction of attention as the first level of situation awareness allows to perceive all relevant elements involved with a given situation. In addition, in the multitasking capacity needed in flights under instrument flight conditions, in brief, in all types of pilot performance, there are big effects of conscious direction of attention. According to Mesulam, the attention mechanism works in such a way that by selecting between mental or environmental events, it directs information processing resources and response channels preferentially towards the most important ones (11). Human information processing capacity is at a level to allow for a limited data throughput in a given time period (12).

Selective attention, as one of the attention processes, is the selection of one out of a number of stimuli. Thus in a noisy environment, thanks to selective attention it is possible to focus only on the explanations of the instructor. Selective attention is also known as concentration (12). For example, upon hearing his or her own call code over the radio, a pilot, using selective attention, directs their attention to the conversation coming in from the wireless. Sustained attention, on the other hand, is the capacity to continue the conscious processing of a series of events that are repeated over a long period and arrive at medium speed. A deficit in sustained attention, together with internal or external stimuli inappropriately triggering irrelevant actions, may cause slips in daily life. For instance, mistakes such as putting salt rather than sugar into the tea or going to a different floor and ringing at the wrong door are familiar to all of us. This kind of slips may be caused by monotonous work, anxiety, or distraction when carrying out several tasks at once (13). One example for such a slip is when a pilot, shortly after take-off and before reaching sufficient altitude, retracts the wing flaps while intending to retract the landing gear.

According to Baddeley, the term working memory refers to a brain system that allows for temporary storage and manipulation of information required for cognitive tasks such as the conceptualization and learning of language and for reasoning (14). Working memory requires the simultaneous storage and processing of information. This ability is important for skills like playing chess. Cummings uses the concept of "mental control" instead of working memory (15). To assess mental control, tests like counting backward, writing words back-to-front, or reading a series of numbers backwards are being used (16). Working memory allows the pilot, when scanning the air space, to remember the relative position and movement of an approaching aircraft and keep it in mind after completing an important task.

Aim of the study is to create norms for commercial pilots in Turkey in a battery of neuropsychological tests. Thus it will be possible to assess if a pilot will be able to do his or her job under circumstances that may affect their cognitive performance negatively. The battery has been designed to measure all aspects of attention such as selective attention, continuous attention, complex attention, and distraction, working memory (as one of the executive functions), speed of information processing, mental flexibility, response time, set transformation, ability to suppress inappropriate responses, as well as various parameters of short- and long-term visual memory (flash memory, learning, spontaneous and recognizing recall) and spatial perception. This battery includes the following tests: WAIS-R (Wechsler Adult Intelligence Scale-Revised) Digit Span, Rey Complex Figure Test (RCFT), Continuous Performance Test (CPT), Paced Auditory Serial Addition Test (PASAT), Reaction Time Test (RTT), d2 Test of Attention (d2TA), Stroop Test (ST), Trail Making Test (TMT), Visual Elevator Test (VET), and Judgement of Line Orientation Test (JLO). In the selection of these tests, the criterion was what tests are being used worldwide in the neuropsychological assessment of pilots. For example, the FAA administers the following neuropsychological tests in aviation: CogScreen-AE (including tests measuring attention, immediate recall, short-term memory, visual perception functions, consecutive functions, logical problem solving, calculation capacity, response time, simultaneous information processing, and executive function skills), TMT, PASAT, CPT (Conner's Continuous Performance Test etc.), verbal memory tests (WMS - Wechsler 
Memory Scale subtest, Visuospatial Memory Test, Rey Test etc.), executive function tests (Wisconsin Test, ST, Halstead Category Test, etc.) (8).

\section{METHOD}

Participants in our study were 147 pilots working for a commercial airline. To ensure correct statistical analyses, it was made sure that the numbers in different age ranges were similar. The age distribution of the pilots was 38 persons $(25.9 \%)$ in the age group $20-29$ years, $43(29.3 \%)$ in the group 30-39 years of age, 30 people $(20.4 \%)$ 40-49 years and $36(24.5 \%)$ aged 50 and above, 144 being male and 3 female. While 131 participants completed the entire battery, 16 could not finish all tests for various reasons (no spectacles, unwilling to participate, etc.). For the study, an appropriate sampling method was used.

Precondition for the study was that participants had no psychiatric history, no symptoms of any diseases, did not use any medications, and in case of spectacle or lens wearers, had the required optical aid with them. As the participant pilots' sleep and prandial state might directly affect their test performance, they were asked about these factors. A participant who reported not to have slept did not withdraw; hungry ones were given a food break of around 15 minutes. As the aim of the study was to establish norms for Turkish pilots working for civilian airlines, foreign nationals were not included.

\section{Measures}

Digit Span Test (DST): This attention test is a subtest of the Wechsler Adult Intelligence Scale that was revised in 1981 (WAIS-R). While the forward digit span test measures basic attention, the reverse digit span test is a function of the working memory (11) and also measures the ability to maintain attention.

As one of the most commonly used tests of shortterm memory, the DST is administered first forward, then backward, in each case increasing one step each. In the forward test, the examiner pronounces several numbers at one-second intervals and the participant has to repeat them in the same order. The sequence of numbers starts with three digits and, depending on the participant's performance, can continue up to 9-digit numbers. In the backward test, numbers have to be repeated back-to-front; the test begins with 2 digits and, depending on performance, can reach up to 8 digits. In the administration of both tests, the measure for the digit span is the number of digits in the last sequence before the participant made a mistake twice in a row. The norm value for the forward digit range is 7 , for the backward digit range 5; results below these results indicate an attention deficit (15).

\section{Rey-Osterrieth Complex Figure Test (ROCF):}

This is a visual perception and long-term visual memory test done with pen on paper, developed by the Swiss psychologist Andre Rey in 1941 (17). In 1944, Paul-Alexandre Osterrieth standardized the test and devised a scoring system (18).

This test assesses perception and memory functions, measuring sequential planning, organizational abilities, problem-solving strategies, and motor functions (19). Initially, the participant is asked to copy a complex drawing. Without requesting that the participant memorize the figure, after a short interval he or she is asked to draw the figure again from memory, thus looking at their short-term memory. Forty minutes later, they are again asked to draw what they remember of the figure, assessing the long-term memory. After the last drawing, the participant is shown different parts and has to decide if they belong to the original figure, demonstrating recognition.

d2 Test of Attention (d2TA): This is a sustained attention and visual scanning ability test developed by Rolf Brickenkamp (20) in 1962, requiring continuous attention and concentration and a quick performance in conformity with the rules (21). The test consists of 14 lines with 47 characters each. In each line, within 20 seconds each "double-marked d (d2)" has to be crossed out. The test takes around 10 minutes.

The last marked " $\mathrm{d} 2$ " in each line gives the score for that line. There are two types of error: " $\mathrm{d} 2$ "s that have been passed over without crossing out are an Error 1 (E1), 
wrongly marked letters are an Error 2 (E2). E1 is found more frequently; it is sensitive to attention control, rule compliance, correct visual scanning, and quality of performance. E2 is found less frequently and is related with inhibitor control, compliance, correct visual scanning, circumspection, and mental flexibility. While E1 and E2 specify the qualitative test performance, the line scores show the quantitative performance. To find the error percentage, E1 and E2 scores are added up, multiplied by 100 and divided by the total line number. The result gives us the error rate for all processed stimuli. A decrease in this rate shows the participant's increased level of attention, a greater quality of the work they have performed, and an increase in correctness (22). A validity and reliability study for d2TA in Turkey found a high internal consistency of the test, making it a reliable measurement instrument (23).

\section{Paced Auditory Serial Addition Test (PASAT):}

This is a cognitive test measuring the ability and speed of processing auditory information, mental flexibility, working memory, and arithmetic capacity. It was developed in 1974 by Gronwall and Sampson to monitor recovery in patients with head trauma (24). To complete the test successfully, a number of cognitive functions, first of all attention-related ones, need to be realized (25). The test is commonly used to follow up MS patients, assessing their cognitive functions (26). PASAT performance has been found to be age-related (27).

In order to control the speed of stimulus presentation, the test can be administered from a CD recording. There are forms A and B for the PASAT; we used form A. In this test, a total of 60 numbers are spoken at intervals of 3 seconds, and the participant has to say the sum of each new number and the previous one. For every 10 additions, the number of correct sums is recorded on a graph, and the resulting curve shows the distribution of attention, while the total number of correct results demonstrates the general level of attention.

Trail Making Test (TMT): A mental flexibility test, giving information about visual-motor scanning, speed of processing, set switching, and executive functions (28). The test consists of forms A and B, each containing 25 circles. In form $\mathrm{A}$, which is administered first, participants have to follow numbers 1 to 25 and connect them sequentially by drawing a line. In the more complex form $B$, circles have to be connected in the sequence number-letter (1-A, 2-B, 3-C...). Form A measures attention, sustained attention, visual scanning, motor reaction speed, and processing speed. Form B is used to measure motor control and complex attention (29).

Both forms of the TMT are given for the same amount of time. If the participant makes a mistake, it is being corrected and the test is completed. There are two different types of mistake: "sequence error" and "perseverative error." In a sequence error, there is a mistake in the sequence of numbers/letters, while in the perseverative error a mistake is made in going from a number to a letter or vice versa. Sometimes participants notice and correct the mistake, while sometimes they may not notice them. A large number of studies assess the test only on the basis of completion time, while others also take the mistakes into consideration (30). The latter approach was chosen for our study.

Continuous Performance Test - A test (CPT): The CPT is a frequently used test to measure attention. It measures not only the capacity for sustained attention, but also response inhibition or disinhibition. The first CPT was developed in 1956 by Rosvold, Mirsky, Sarason, Bransome, and Beck as a research instrument to study vigilance (31).

There are different versions of CPT, with or without the use of computers, and the duration of their administration varies (32). We used the A test, which does not involve computers. At the first stage of this test, a sequence of 82 random letters is read to the participants for 1 second each, and each time the letter A is read out, participants are expected to knock on the table. At the second stage, the same letter sequence is read backwards, and this time the participants are to knock on the table each time the letter $\mathrm{A}$ is read out after a letter $\mathrm{E}$. The total number of correct responses is calculated and evaluated. While distractible persons tend to omit letters, people with a disinhibition 
problem may respond to stimuli other than the letter A. It is expected that subjects with normal attention complete the test without errors (15).

Elevator test (ET): Developed by Robertson et al. (33) in 1994, the ET is a subtest of the Test of Everyday Attention (TEA) and has been found to be closely related with the IO. This test has been seen to be consistent with Backward Digit Span and PASAT in measuring auditory and verbal working memory.

In this test, participants have to count visually presented elevator doors going downwards and upwards, following arrows. For example, when seeing a downward arrow while counting elevator doors 1, 2, 3,4 , they are supposed to continue $3,2,1$. The ET measures distraction and mental flexibility (34). Criteria for the evaluation of the test are completion time and number of errors.

Reaction Time Test (RTT): There are several tests available for use on the computer. For ease of access and administration, we used Gary Darby's reaction time test from 2006, available at the website www.DelphiForFun.org. This test measures the time to react to a previously defined visual or auditory stimulus. Whenever the participant sees an image on the screen or hears a sound, they press the space bar as quickly as possible. Within around 6 minutes, a total of 90 audiovisual stimuli are presented. Thereby, visual and auditory reaction times can be assessed separately. To begin with, while administering the test, two visual and auditory assessments are made whose scores are not included in the test score. At the end of the test, the following scores are obtained: RT1 (visual reaction time 1), RT2 (visual reaction time 2), RT3 (visual reaction time 3 ), RT4 (visual reaction time 4), RT5 (visual reaction time 5), RST (reaction in shortest time), and UST (Reaction Time Test for Moving Object).

Previous studies found reaction time to be correlated with age (35) and lack of sleep (36).

Stroop Test (ST): The ST is a practical attention test used mainly to establish brain damage or measure selective attention and mental flexibility (37).
Developed by John Ridley Stroop in 1935, it measures the speed of information processing and the capacity to confront the deceptive effect of automatic function processes (Stroop effect) $(38,39)$, measuring if subjects are able to name colors correctly, suppressing their reading facility. Particularly after the age of 60 , the Stroop (interference) effect is observed, and the test has been found to be related with the level of education $(39,37)$.

There are different versions of the ST. We used the TBAG Form that is included in the BILNOT Battery, consisting of the original ST and the Victoria form (38). With this form, the participants are shown 4 cards in 5 different ways, each card containing 24 words or figures. The duration of the administration of each card is timed and the number of errors/corrections is recorded. On the first card, the names of colors to be read out are printed in black. On the second card, the names of colors to be read out are printed in different colors. On the third card, the colors of figures are to be named. The fourth card contains words other than the names of colors, printed in color; the participants are requested to name the colors of the words. Finally, participants have to name the color of words on a card where the names of colors are printed in a color different from the color referred to by the word.

Judgement of Line Orientation (JLO): Developed by Benton et al. (40) in 1978 to measure spatial perception, the test is based upon establishing angular similarity between lines. It is mainly used to assess lesions in the right parietal lobe (41). Forty-six percent of patients with a lesion in the right brain and $10 \%$ of patients with a left-brain lesion show a low performance in this test, which indicates a correlation with right-brain damage. In addition, persons with a lower level of education tend to perform less well at the test (40).

There are two versions of the test, $\mathrm{V}$ and $\mathrm{H}$, which are presenting the same elements in a different order. We used the $\mathrm{H}$ version. In the upper half, the test booklet shows 2 lines as stimuli, while in the lower half, for each question there is the same choice of answers. In the test, participants have to establish the orientation of 30 line pairs, from easy to difficult, in reference to lines 
in the lower half that are numbered from 1 through 11 . To score a point, the participant has to give the correct answer for the orientation of both lines; otherwise (even if the orientation of one of the lines is given correctly), no point is awarded. The sum of the scores from the 30 items is the total JLO score (38).

\section{Procedure}

This study was carried out in the remit of the health board of a commercial airline. Data were collected from pilots in employment between August 2012 and October 2014. At the beginning, the required permissions from the administration of the company were received. Subsequently, participants were recruited randomly according to the established numbers by age group. The tests included in the neuropsychological battery were administered by a specialist psychologist who had completed neuropsychological test training and done an internship in the relevant area.

Participants received written and oral information about the aim of the study. Those who did not volunteer were not enrolled in the study. Before taking the test, a preliminary interview with the participants was carried out to assess their suitability according to the study criteria. The mean duration of administering the test battery was 2 hours. The tests were carried out for each participant individually in a quiet room with normal lighting that was appropriate for the conditions of testing. Tests were given in the following sequence: WAIS-R DST, RCFT, CPT, PASAT, RTT, d2DT, ST, TMT, ET, and JLO. Scores for all tests in the battery were recorded and assessed according to the respective guidelines. The effects of the factors age, higher education state, handedness, and flight experience on the battery were assessed.

\section{Statistical Analysis}

As variables in the analysis of the test results, we used age, flight experience, hand preference, military vs. civilian background, and level of higher education. In the first step, a descriptive analysis was carried out; as the sample size was above 60, the Kolmogorov-Smirnov test was used to test for normal distribution. Only one value (REY3 score) passed the test of normality ( $p>0.05$ ). Data distribution was found to be skewed, and after this step, subjects and variables with outliers were established. For the dependent variables in the data, outliers were found for 31 subjects. After excluding the subjects who had produced outliers, the test of normality was run again. Seven scores passed the normality test. This situation showed that discarding outliers was not useful. As ours was a norm study, expected subsequent transformations could not be performed in order to avoid changing the nature of the data.

In order to determine likely combinations of the variables, cross tabulations and chi-square analyses were done. Given that our groups did not show normal distribution and therefore did not meet the conditions for parametric statistics, we applied nonparametric statistics.

For comparisons between groups, we used chisquare and Kruskal-Wallis tests. With the chi-square test, we analyzed the frequency distribution of specific variables (e.g., military vs. civilian background) for the subjects, while the Kruskal-Wallis test assessed if there was a difference for each variable (e.g., military vs. civilian background) between the mean scores of the neuropsychological test. Mean scores and standard deviation were calculated by age group and a paired age group comparison was made analyzing the test scores using Mann-Whitney $U$ test.

For parametrical comparisons, t-test was used for paired comparisons, while the ANOVA test was applied for factors with a level of more than two independent variables.

\section{RESULTS}

\section{A. Descriptive statistics}

\section{1) Descriptive Statistics of Test Values}

Minimum and maximum test scores, mean values and standard deviations for all participants are shown in Table 1. 
Table 1: Number of participants, minimum, maximum and mean score, and standard deviation for all tests

\begin{tabular}{|c|c|c|c|c|c|}
\hline & Number & Minimum & Maximum & Mean & Standard Deviation \\
\hline \multicolumn{6}{|l|}{ Digit Span Test } \\
\hline Digit Span Test forward & 147 & 4 & 9 & 7.16 & 1.29 \\
\hline Digit Span Test reverse & 147 & 3 & 9 & 6.12 & 1.46 \\
\hline \multicolumn{6}{|l|}{ Rey Osterrieth Test } \\
\hline Rey 1 (Copy score) & 147 & 30 & 36 & 35.74 & 0.82 \\
\hline Rey 2 (Immediate Recall score) & 147 & 11 & 34 & 24.42 & 4.91 \\
\hline Rey 3 (Delayed Recall score) & 147 & 11 & 34 & 24.29 & 4.77 \\
\hline Correct Recognition total scores & 147 & 3 & 12 & 8.05 & 1.91 \\
\hline \multicolumn{6}{|l|}{ Continuous Performance Test } \\
\hline Continuous Performance Test 1 & 147 & 17 & 20 & 19.87 & 0.41 \\
\hline Continuous Performance Test 2 & 147 & 1 & 5 & 4.61 & 0.7 \\
\hline \multicolumn{6}{|l|}{ PASAT } \\
\hline PASAT & 147 & 31 & 60 & 55.9 & 5.19 \\
\hline \multicolumn{6}{|l|}{ Reaction Time Test } \\
\hline RT1 (Reaction Time Test 1) & 133 & 0.21 & 0.39 & 0.29 & 0.03 \\
\hline RT2 (Reaction Time Test 2) & 133 & 0.22 & 0.57 & 0.28 & 0.04 \\
\hline RT3 (Reaction Time Test 3) & 133 & 0.22 & 0.40 & 0.28 & 0.03 \\
\hline RT4 (Reaction Time Test 4) & 133 & 0.22 & 0.73 & 0.33 & 0.08 \\
\hline RT5 (Reaction Time Test 5) & 133 & 0.13 & 0.43 & 0.30 & 0.03 \\
\hline RST (Reaction in Shortest Time) & 133 & 0.18 & 0.64 & 0.39 & 0.14 \\
\hline UST (Reaction Time Test for Moving Object) & 133 & 0.22 & 0.45 & 0.30 & 0.03 \\
\hline \multicolumn{6}{|l|}{ d2 Test } \\
\hline Total sequence score & 145 & 390 & 687 & 572.01 & 64.13 \\
\hline Total error score & 145 & 0 & 121 & 24.10 & 18.41 \\
\hline Total sequence minus total error score & 145 & 54 & 679 & 541.66 & 82.72 \\
\hline Maximum value minus minimum value & 145 & 1.00 & 24 & 10.62 & 5.08 \\
\hline Error distribution & 145 & 0 & 21.5 & 4.28 & 3.46 \\
\hline \multicolumn{6}{|l|}{ Stroop Test } \\
\hline Stroop 1. Duration of Cards & 147 & 5 & 17 & 7.82 & 1.85 \\
\hline Stroop 1. Number of card errors & 147 & 0 & 0 & 0 & 0 \\
\hline Stroop 1. Number of card corrections & 147 & 0 & 1 & 0 & 0.08 \\
\hline Stroop 2. Duration of cards & 147 & 5 & 27 & 9.05 & 2.95 \\
\hline Stroop 2. Number of card errors & 147 & 0 & 0 & 0 & 0 \\
\hline Stroop 2. Number of card corrections & 147 & 0 & 1 & 0.02 & 0.14 \\
\hline Stroop 3. Duration of cards & 147 & 6 & 17 & 10.30 & 1.99 \\
\hline Stroop 3. Number of card errors & 147 & 0 & 1 & 0.02 & 0.14 \\
\hline Stroop 3. Number of card corrections & 147 & 0 & 2 & 0.15 & 0.41 \\
\hline Stroop 4. Duration of cards & 147 & 7 & 23 & 12.63 & 3.05 \\
\hline Stroop 4. Number of card errors & 147 & 0 & 0 & 0 & 0 \\
\hline Stroop 4. Number of card corrections & 147 & 0 & 4 & 0.15 & 0.5 \\
\hline Stroop 5. Duration of cards & 147 & 5 & 37 & 18.64 & 4.91 \\
\hline Stroop 5. Number of card errors & 147 & 0 & 3 & 0.17 & 0.49 \\
\hline Stroop 5. Number of card corrections & 147 & 0 & 4 & 0.57 & 0.9 \\
\hline \multicolumn{6}{|l|}{ Trail making test } \\
\hline Trail making test Form A & 146 & 11 & 60 & 27.48 & 9.01 \\
\hline Trail making form A number of errors & 146 & 0 & 1 & 0.02 & 0.16 \\
\hline Trail making form B number of errors & 146 & 23 & 122 & 55.10 & 18.17 \\
\hline Trail making form B number of errors & 146 & 0 & 4 & 0.34 & 0.71 \\
\hline \multicolumn{6}{|l|}{ Elevator test } \\
\hline Elevator test number of changes & 146 & 0.26 & 5.5 & 2.98 & 0.7 \\
\hline Elevator test total time & 146 & 71 & 199 & 116.11 & 26.44 \\
\hline Elevator test number of changes & 146 & 10 & 40 & 38.86 & 2.84 \\
\hline \multicolumn{6}{|l|}{ Line orientation test } \\
\hline Line orientation test & 136 & 10 & 30 & 26.59 & 3.08 \\
\hline
\end{tabular}


Table 2: Overview table of mean values and standard deviations and ANOVA and Post Hoc analysis results by age group

\begin{tabular}{|c|c|c|c|c|c|c|c|c|c|c|c|}
\hline \multirow{3}{*}{ Tests } & \multicolumn{8}{|c|}{ Age groups } & \multirow{3}{*}{$\mathbf{p}$} & \multirow{3}{*}{$\mathbf{F}$} & \multirow{3}{*}{ Post Hoc } \\
\hline & \multicolumn{2}{|c|}{$20-29(A)$} & \multicolumn{2}{|c|}{$30-39$ (B) } & \multicolumn{2}{|c|}{$40-49(\mathrm{C})$} & \multicolumn{2}{|c|}{$50+(D)$} & & & \\
\hline & Mean & SD & Mean & SD & Mean & SD & Mean & SD & & & \\
\hline \multicolumn{12}{|l|}{ Digit Span Test } \\
\hline Digit Span Test forward & 7.84 & 1.03 & 7.47 & 1.12 & 7.00 & 1.39 & 6.22 & 1.10 & $\mathrm{p}<0.001$ & 13.577 & $\mathrm{~A}>\mathrm{C}, \mathrm{D} ; \mathrm{B}>\mathrm{D} ; \mathrm{C}>\mathrm{D}$ \\
\hline Digit Span Test reverse & 6.95 & 0.87 & 6.47 & 1.32 & 6.03 & 1.59 & 4.92 & 1.27 & $\mathrm{p}<0.001$ & 17.279 & $\mathrm{~A}>\mathrm{C}, \mathrm{D} ; \mathrm{B}>\mathrm{D} ; \mathrm{C}>\mathrm{D}$ \\
\hline \multicolumn{12}{|l|}{ Rey Osterrieth Test } \\
\hline Rey 1 (Copy score) & 35.92 & 0.36 & 35.81 & 0.59 & 35.97 & 0.18 & 35.28 & 1.41 & 0.001 & 5.708 & $\mathrm{~A}>\mathrm{D} ; \mathrm{B}>\mathrm{D} ; \mathrm{C}>\mathrm{D}$ \\
\hline Rey 2 (Immediate Recall score) & 26.74 & 4.65 & 24.84 & 4.24 & 24.35 & 4.91 & 21.57 & 4.68 & $\mathrm{p}<0.001$ & 7.951 & $\mathrm{~A}>\mathrm{D} ; \mathrm{B}>\mathrm{D}$ \\
\hline Rey 3 (Delayed Recall score) & 26.88 & 4.33 & 24.2 & 4.21 & 23.87 & 5.01 & 21.19 & 3.94 & $\mathrm{p}<0.001$ & 1.954 & \\
\hline Correct Recognition total score & 8.61 & 1.94 & 8.19 & 2.05 & 8.10 & 1.52 & 7.28 & 1.86 & 0.025 & 3.224 & $A>D$ \\
\hline \multicolumn{12}{|l|}{ Continuous Performance Test } \\
\hline Continuous Performance Test 1 & 19.87 & 0.34 & 19.93 & 0.26 & 19.93 & 0.25 & 19.75 & 0.65 & 0.193 & 1.638 & \\
\hline Continuous Performance Test 2 & 4.47 & 0.95 & 4.77 & 0.61 & 4.80 & 0.41 & 4.44 & 0.65 & 0.051 & 0.029 & \\
\hline \multicolumn{12}{|l|}{ PASAT } \\
\hline PASAT & 58.37 & 2.11 & 56.79 & 4.09 & 56.53 & 3.57 & 51.72 & 7.17 & $p<0.001$ & 17.255 & $\mathrm{~A}>\mathrm{D} ; \mathrm{B}>\mathrm{D} ; \mathrm{C}>\mathrm{D}$ \\
\hline \multicolumn{12}{|l|}{ Reaction Time Test } \\
\hline RT1 (Reaction Time Test 1) & 0.26 & 0.03 & 0.28 & 0.03 & 0.30 & 0.04 & 0.31 & 0.04 & $\mathrm{p}<0.001$ & 10.416 & $\mathrm{D}, \mathrm{C}>\mathrm{A} ; \mathrm{D}>\mathrm{B}$ \\
\hline RT2 (Reaction Time Test 2) & 0.26 & 0.02 & 0.28 & 0.03 & 0.31 & 0.07 & 0.30 & 0.04 & $\mathrm{p}<0.001$ & 8.565 & $\mathrm{D}, \mathrm{C}>\mathrm{A} ; \mathrm{C}>\mathrm{B}$ \\
\hline RT3 (Reaction Time Test 3) & 0.27 & 0.02 & 0.28 & 0.03 & 0.31 & 0.04 & 0.30 & 0.03 & $\mathrm{p}<0.001$ & 7.940 & $\mathrm{D}, \mathrm{C}>\mathrm{A} ; \mathrm{C}>\mathrm{B}$ \\
\hline RT4 (Reaction Time Test 4) & 0.30 & 0.05 & 0.33 & 0.08 & 0.34 & 0.06 & 0.36 & 0.12 & 0.022 & 3.329 & $\mathrm{D}>\mathrm{A}$ \\
\hline RT5 (Reaction Time Test 5) & 0.28 & 0.04 & 0.30 & 0.03 & 0.32 & 0.03 & 0.32 & 0.04 & $\mathrm{p}<0.001$ & 7.841 & $\mathrm{D}, \mathrm{C}, \mathrm{B}>\mathrm{A}$ \\
\hline RST (Reaction in Shortest Time) & 0.29 & 0.09 & 0.41 & 0.15 & 0.48 & 0.14 & 0.40 & 0.14 & $\mathrm{p}<0.001$ & 11.223 & $\mathrm{D}, \mathrm{C}, \mathrm{B}>\mathrm{A}$ \\
\hline $\begin{array}{l}\text { UST (Reaction Time Test for Moving } \\
\text { Object) }\end{array}$ & 0.28 & 0.02 & 0.30 & 0.03 & 0.32 & 0.03 & 0.31 & 0.05 & 0.001 & 5.710 & $\mathrm{D}, \mathrm{C}>\mathrm{A}$ \\
\hline \multicolumn{12}{|l|}{ d2 Test } \\
\hline Total sequence score & 597.08 & 47.60 & 578.24 & 61.41 & 568.87 & 72.83 & 540.03 & 63.82 & 0.001 & 5.455 & $\mathrm{~A}, \mathrm{~B}>\mathrm{D}$ \\
\hline Total error score & 23.11 & 22.01 & 23.40 & 15.57 & 22.57 & 12.44 & 27.34 & 21.69 & 0.695 & 0.483 & \\
\hline Total sequence minus total error score & 573.71 & 47.98 & 547.64 & 71.6 & 539.83 & 92.74 & 501.26 & 100.43 & 0.002 & 5.177 & $A>D$ \\
\hline Maximum value minus minimum value & 9.13 & 4.55 & 11.12 & 5.47 & 9.60 & 5.02 & 12.54 & 4.70 & 0.018 & 3.453 & $\mathrm{D}>\mathrm{A}$ \\
\hline Error distribution & 3.64 & 3.55 & 4.10 & 2.72 & 3.95 & 2.06 & 5.51 & 4.75 & 0.107 & 2.069 & \\
\hline Stroop Test & & & & & & & & & & & \\
\hline Stroop 1. Duration of Cards & 7.26 & 1.46 & 7.65 & 1.57 & 8.40 & 2.30 & 8.17 & 1.99 & 0.045 & 2.749 & Not significant \\
\hline Stroop 1. Number of card errors & 0.00 & 0.00 & 0.00 & 0.00 & 0.00 & 0.00 & 0.00 & 0.00 & - & & \\
\hline Stroop 1. Number of card corrections & 0.00 & 0.00 & 0.00 & 0.00 & 0.00 & 0.00 & 0.03 & 0.17 & 0.382 & 1.028 & \\
\hline Stroop 2. Duration of cards & 7.58 & 1.64 & 8.28 & 1.76 & 9.13 & 1.98 & 11.47 & 4.19 & $\mathrm{p}<0.001$ & 15.877 & $\mathrm{D}>\mathrm{A}, \mathrm{B}, \mathrm{C}$ \\
\hline Stroop 2. Number of card errors & 0.00 & 0.00 & 0.00 & 0.00 & 0.00 & 0.00 & 0.00 & 0.00 & - & . & \\
\hline Stroop 2. Number of card corrections & 0.03 & 0.16 & 0.00 & 0.00 & 0.00 & 0.00 & 0.06 & 0.23 & 0.287 & 1.269 & \\
\hline Stroop 3. Duration of cards & 9.55 & 1.66 & 9.63 & 1.73 & 10.33 & 1.65 & 11.89 & 2.04 & $\mathrm{p}<0.001$ & 13.884 & $\mathrm{D}>\mathrm{A}, \mathrm{B}, \mathrm{C}$ \\
\hline Stroop 3. Number of card errors & 0.03 & 0.16 & 0.00 & 0.00 & 0.00 & 0.00 & 0.06 & 0.23 & 0.287 & 1.269 & \\
\hline Stroop 3. Number of card corrections & 0.16 & 0.37 & 0.02 & 0.15 & 0.10 & 0.40 & 0.36 & 0.59 & 0.003 & 4.897 & $\mathrm{D}>\mathrm{B}, \mathrm{C}$ \\
\hline Stroop 4. Duration of cards & 10.95 & 1.79 & 11.26 & 1.85 & 12.60 & 2.11 & 16.08 & 3.18 & $\mathrm{p}<0.001$ & 39.495 & $\mathrm{D}>\mathrm{A}, \mathrm{B}, \mathrm{C} ; \mathrm{C}>\mathrm{A}$ \\
\hline Stroop 4. Number of card errors & 0.00 & 0.00 & 0.00 & 0.00 & 0.00 & 0.00 & 0.00 & 0.00 & - & . & \\
\hline Stroop 4. Number of card corrections & 0.16 & 0.44 & 0.02 & 0.15 & 0.10 & 0.40 & 0.36 & 0.80 & 0.025 & 3.220 & $\mathrm{D}>\mathrm{B}$ \\
\hline Stroop 5. Duration of cards & 15.84 & 3.51 & 17.23 & 3.75 & 18.27 & 3.65 & 23.61 & 4.84 & $\mathrm{p}<0.001$ & 27.004 & $\mathrm{D}>\mathrm{A}, \mathrm{B}, \mathrm{C}$ \\
\hline Stroop 5. Number of card errors & 0.18 & 0.39 & 0.12 & 0.39 & 0.03 & 0.18 & 0.36 & 0.76 & 0.039 & 2.854 & $\mathrm{D}>\mathrm{C}$ \\
\hline Stroop 5. Number of card corrections & 0.58 & 0.92 & 0.53 & 0.88 & 0.57 & 0.82 & 0.61 & 1.02 & 0.987 & 0.046 & \\
\hline Trail making test & & & & & & & & & & & \\
\hline Trail making test Form A & 25.76 & 8.22 & 24.14 & 5.70 & 26.83 & 10.69 & 33.83 & 8.72 & $\mathrm{p}<0.001$ & 10.017 & $\mathrm{D}>\mathrm{A}, \mathrm{B}, \mathrm{C}$ \\
\hline Trail making form A number of errors & 0.00 & 0.00 & 0.07 & 0.26 & 0.00 & 0.00 & 0.03 & 0.17 & 0.191 & 1.604 & \\
\hline Trail making form $B$ number of errors & 50.16 & 14.38 & 47.35 & 12.33 & 55.07 & 20.77 & 69.64 & 17.46 & $\mathrm{p}<0.001$ & 14.310 & $\mathrm{D}>\mathrm{A}, \mathrm{B}, \mathrm{C}$ \\
\hline Trail making form $B$ number of errors & 0.24 & 0.59 & 0.26 & 0.62 & 0.45 & 0.69 & 0.50 & 0.91 & 0.297 & 1.301 & \\
\hline Elevator test & & & & & & & & & & & \\
\hline Elevator test number of changes & 2.61 & 0.75 & 2.82 & 0.65 & 3.02 & 0.63 & 3.56 & 0.75 & $\mathrm{p}<0.001$ & 12.561 & $\mathrm{D}>\mathrm{A}, \mathrm{B}, \mathrm{C}$ \\
\hline Elevator test total time & 104.87 & 24.24 & 107.09 & 19.42 & 115.38 & 21.28 & 139.36 & 25.85 & $\mathrm{p}<0.001$ & 17.853 & $\mathrm{D}>\mathrm{A}, \mathrm{B}, \mathrm{C}$ \\
\hline Elevator test number of changes & 39.42 & 0.76 & 38.51 & 4.60 & 39.14 & 1.09 & 38.50 & 2.41 & 0.398 & 0.994 & \\
\hline Line orientation test & & & & & & & & & & & \\
\hline Line orientation test & 26.32 & 3.95 & 27.85 & 2.13 & 26.24 & 3.07 & 25.72 & 2.81 & 0.016 & 3.573 & $D>B$ \\
\hline
\end{tabular}




\section{2) Descriptive Statistics for Demographic Data}

Of all subjects, $83.0 \%$ were right-handed and $11.6 \%$ left-handed, while $5.4 \%$ were ambidextrous. Eighty-eight subjects $(59.9 \%)$ were from a civilian background, 59 (40.1\%) from a military one. According to their flight experience, we divided them into 4 groups: 1 -2 years (30.6\%), 3-10 years $(20.4 \%)$, $11-25$ years $(24.5 \%)$, and 26 years and above $(24.5 \%)$.

For the statistical analysis of higher education status, we combined some diploma groups. The resulting distribution was the following: engineering $36.7 \%$, air force academy $33.3 \%$, economy and administrative sciences (management, economics, econometrics, public administration, finance) $8.8 \%$, piloting $8.8 \%$, naval war academy or army war academy $6.1 \%$, other schools (medicine, physics, music, information technology, astronomy and space science, industrial design, computer programming) $6.1 \%$.

\section{B. Cross Tabulation and Chi-Square $\left(\chi^{2}\right)$ Analyses for Demographic Variables}

For all likely combinations of the variables age, type of diploma, military vs. civilian background, handedness, and flight experience, chi-square analyses were carried out. A significant correlation was found between age and higher degree $\left(\chi^{2}=127.076, \mathrm{df}=15, \mathrm{p}<0.001\right)$.

The result of the chi-square analysis between age groups and military-civilian background was found to be significant; while the older participants had mainly graduated from military academies, the younger ones came from civilian schools $\left(\chi^{2}=115.096, \mathrm{df}=3, \mathrm{p}<0.001\right)$. According to their higher education, $60.5 \%$ of the age group 20-29 years had graduated from engineering, $62.7 \%$ of the age group 30-39 years; of the age group $40-49,63.3 \%$ had graduated from the air force academy (military background), as had $83.3 \%$ of the age group 50 years and above. In numbers, the age groups according to military vs. civilian background were: 20-29 years (38 civilian - no military); 30-39 years (42 civilian - 1 military), 40-49 years (6 civilian - 24 military), 50 years and above (2 civilian - 34 military).

Results of chi-square analysis for diploma and hand preference were not found significant. In the various diploma groups, an even distribution of handedness was found. Equally, the chi-square analysis for military vs. civilian background and handedness had no significant result. In the military and civilian groups, handedness was distributed evenly.

\section{Nonparametric Comparisons}

All mean test scores by age group, standard deviation, and results of statistical comparisons of age groups are presented in Table 2. Tests finding a statistically significant difference $(p<0.05)$ in the paired age-group comparisons using Mann-Whitney $U$ test are reported in Table 3.

\section{Table 3: Tests with significant results by age group}

\begin{tabular}{|c|c|}
\hline Age Groups & Significant Tests \\
\hline $20-29 / 30-39$ & $\begin{array}{l}\text { Rey test } 2 \text { scores, RT1 (Visual reaction time 1), RT2 (Visual reaction time 2), RTS (Auditory reaction time), RST (Shortest reaction time), } \\
\text { UST (Longest reaction time), Stroop test } 2 \text {. card duration, Stroop test } 3 \text {. card number of corrections }\end{array}$ \\
\hline $20-29 / 40-49$ & $\begin{array}{l}\text { Digit span test forward and reverse scores, all Rey test scores, PASAT, all Reaction time test scores, all d2 test scores exc. total errors, } \\
\text { Stroop test 1. 2. 3. 4. 5. card duration scores, Trail making test form A duration, Form B number of errors, Elevator test all scores }\end{array}$ \\
\hline $20-29 / 50+$ & $\begin{array}{l}\text { Continuous performance test } 1 \text { and } 2, \mathrm{~d} 2 \text { test total errors, Stroop test for all cards number of errors and corrections, Trail making test } \\
\text { forms } \mathrm{A} \text { and } \mathrm{B} \text { all scores exc. number of errors }\end{array}$ \\
\hline $30-39 / 40-49$ & $\begin{array}{l}\text { RT1, RT2, RT3 (Visual reaction duration 1, 2, 3), RST (Shortest reaction time), Stroop test 2. and 4. card duration and Line orientation test } \\
\text { scores }\end{array}$ \\
\hline $30-39 / 50+$ & $\begin{array}{l}\text { Digit span test forward and reverse scores, Rey test 1, Rey test 2, Rey test } 3 \text { scores, Continuous performance test } 2 \text {, PASAT scores, RT1 } \\
\text { (Visual reaction time 1) and RT2 (Visual reaction time 2), d2 test TL (Total lines) and TL-TE (Total lines minus total errors) scores, Stroop } \\
\text { test 2. 3. 4. and 5. card duration, 3. and 4. card number of corrections, Trail making test form A duration, Trail making test form B number } \\
\text { of errors, Elevator test total and change duration, Line orientation test }\end{array}$ \\
\hline $40-49 / 50+$ & $\begin{array}{l}\text { All Rey test scores, Continuous performance test 2, PASAT, RST (Shortest reaction time), d2 test TL-TE (total lines minus total errors), } \\
\text { max-min TL (diff. longest duration and shortest duration), Stroop 2. 3. 4. and 5. card durations, 3. card number of corrections, } 5 \text {. card } \\
\text { number of errors, Trail making test form A duration, form B number of errors, Elevator test total duration and change duration }\end{array}$ \\
\hline
\end{tabular}




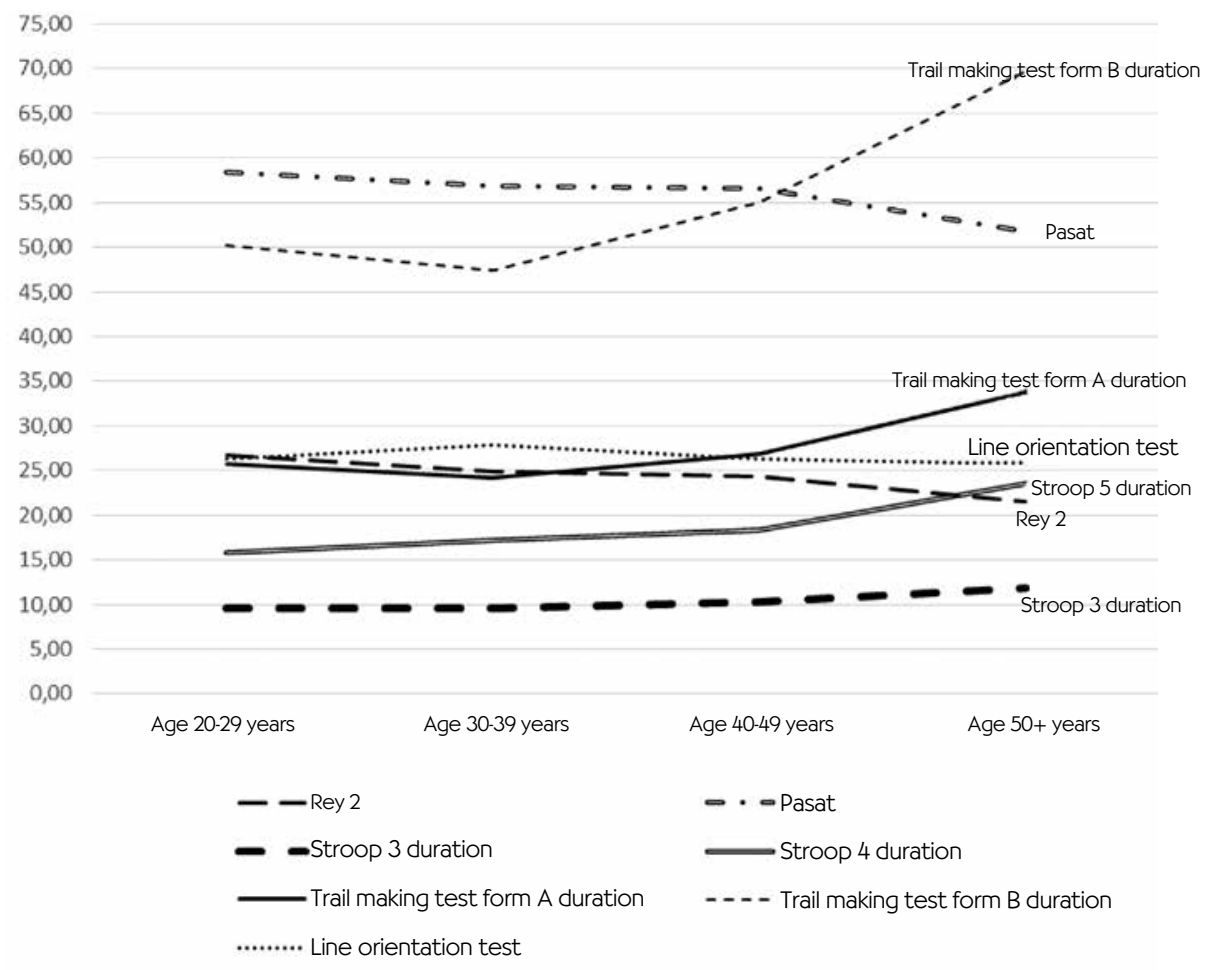

Figure 1: Comparison of test scores according to age groups

Some of the test scores where the comparison by age group resulted in statistical significance are presented as a graph in Figure 1.

\section{DISCUSSION}

We believe that the findings from our study are functional to be used for the required neuropsychological assessment of pilots. As we have seen, the age parameter needs to be taken as a norm, while the parameters higher education, military vs. civilian background, handedness, and flight experience were no significant norm criteria.

If we want to support the initial view of our study that norm values for civil aviators differ from those in society as a whole, it will be useful to compare our results with the norm values in general society. A norm determination study for the TMT in Turkey with an age range of 20-49 years provided data for age groups 20-29, 30-39, and 40-49 years (42). Similar to our study, this work determined norm values in a sample of male subjects with an education of 12 years an above. While not being compared statistically, a comparison of the resulting data between pilot and normal sample groups showed a conspicuous difference. In the Turkish norm, in the age group 20-29 years the duration of form A was $34.08 \pm 12.32$ and for form $B$ 66.68 \pm 22.81 ; in the age group 30-39 years, the duration of form A was $35.48 \pm 9.44$ and for form B $68.43 \pm 23.18$; in the age group 40-49 years, the duration of form A was $38.13 \pm 9.53$ and for form B $79.63 \pm 24.72$. In the pilot norm, however, in the age group 20-29 years the duration of form A was $25.74 \pm 8.22$ and for form $B 50.16 \pm 14.38$; in the age group 30-39 years, the duration of form $A$ was $24.14 \pm 5.70$ and for form B 47.35 \pm 12.33 ; in the age group 40-49 years, the duration of form $A$ was $26.83 \pm 10.69$ and for form B 55.07 \pm 20.77 .

A norm study for BILNOT (Neuropsychological Test Battery for Cognitive Potentials) by Karakas et al. (38) provides data for age groups 20-54 and 55-82 years. Even though the age groups in our study do not quite match the groups used in the ST norm study in the BILNOT battery, the differences provide interesting 
ideas. For example, the duration of completing section 4 in the society sample was 16.95 in age group 20-54 years and 24.87 in age group 55-82 years, while in the pilot sample, in age group 20-29 years it was 10.95, in the 30-39 group 11.26, in the group 40-49 years 12.60 , and in the group 50 years and above 16.08. Finally, the duration of completing section 5 , which measures resistance to distractors, was 26.38 in age group 20-54 years and 35.96 in age group 55-82 years in the society sample, while in the pilot sample it was 15.84 in age group 20-29 years, 17.23 in age group 30-39 years, 18.27 in age group 40-49 years, and 23.61 in age group 50 years and above, suggesting a relevant difference between data for pilots and for society as a whole. Determining the statistical significance of these differences could be the topic of another study. As there are no personal data before disease, it is appropriate to assess pilots according to professional norms.

King et al. (43) pointed out that the main purpose of cognitive tests administered to pilot candidates before training together with other examinations was to archive data regarding cognitive functioning in order to use them when the need arises. Thus, rather than assessing individuals with the norms of a wide population, it is recommended to evaluate them within their own norm. Archiving the results will be important when assessing pilots' fitness to fly after a future disease or accident that may cause cognitive impairment or in case that the pilot displays psychiatric, neurological, or drug-related changes. Similarly, we also think that it will be useful to set up an archive for cognitive data obtained from pilots at the initial stage of entering the profession.

We found a significant relation between age and higher education. While young pilots are mainly graduates from civilian schools, most subjects in the group 40 and above are graduates from military academies. We compared the test scores according to the pilots' military vs. civilian background and higher education and found a statistically significant difference. However, we found that military vs. civilian background and education factors were affected by the age factor and statistical significance depended upon age.
In society as a whole, right-handedness is found in $85-90 \%$ of the population (44). In our sample, however, right-handedness stood slightly below the society rate at $83 \%$. No significant relation was found between higher education and hand preference.

Looking at all test results, we find that performance drops significantly in the age range 50-59 years. PASAT performance was found to be related with age. In accordance with the literature, we found reduced PASAT performance with increasing age (27). Among the factors affecting PASAT scores, low IO and low level of mathematics have been found (24). However, as the specified factors were not effective in our sample, PASAT mostly measures attention. With regard to the duration of TMT, the study by Tombaugh reached similar results, the performance being inversely related with age (28). In particular, the duration of form $B$ was significantly prolonged from age 40 upwards. In contrast with our results, a study by Cangoz et al. (30) in 2007 found that test completion speed did not change with increasing age, but the error rate went up. The JLO performance showed an interesting age-related distribution. While the results for age ranges 20-29 and 40-49 years were very similar, performance was higher in the age range 30-39 years.

One of the limitations of our study is the fact that for reasons of time limits, we did not administer any test assessing verbal memory processes. In future studies, it will be useful to assess verbal memory processes as well. It may be thought that including pilots from only one airline into the sample is another limitation; however, this may be less of a limitation considering that pilots changing employer are not undergoing any neuropsychological or ability tests and that the study was done in a company that employs a major part of the commercial pilots working in Turkey. A further limitation might be that we did not examine the factor of the different history of airplane types among pilots with a military background, which may be thought to affect the age difference. Finally, it may be useful for civil aviation to carry out studies comparing hand preferences in samples of pilots and non-pilots. 


\begin{tabular}{|l|l|l|}
\hline \multicolumn{2}{|l|}{ Contribution Categories } & Author Initials \\
\hline \multirow{4}{*}{ Category 1} & Concept/Design & Z.O.A., D.E., C.K. \\
\cline { 2 - 3 } & Data acquisition & Z.O.A., C.K. \\
\cline { 2 - 3 } & Data analysis/Interpretation & Z.O.A., D.E., C.K. \\
\hline \multirow{3}{*}{ Category 2} & Drafting manuscript & Z.O.A., D.E., C.K. \\
\cline { 2 - 3 } & Critical revision of manuscript & Z.O.A., D.E., C.K. \\
\hline Category 3 & Final approval and accountability & Z.O.A., D.E., C.K. \\
\hline \multirow{4}{*}{ Other } & Technical or material support & N/A \\
\cline { 2 - 3 } & Supervision & N/A \\
\cline { 2 - 3 } & Securing funding (if applicable) & N/A \\
\hline
\end{tabular}

\section{REFERENCES}

1. Oktem $\bigcirc$. Points to be taken into account in neuropsychological assessments. Journal of Neuropsycholgy 2012; 1:8-13. (Turkish)

2. Karakas S, Kafadar H. Neuropsychological tests fort he assessment of cognitive processes in schizophrenia. Schizophrenia Series 1999; 2:132-152. (Turkish)

3. Maschke P, Oubaid V, Pecena Y. How do astronaut candidate profiles differ from airline pilot profiles? Aviation Psychology and Applied Human Factors 2011; 1:38-44. [CrossRef]

4. King R. Psychological testing for mental health screening, suitability determinations and archival purposes to improve safety and reduce costs. EAAP Konference for Aviation Psychology and Applied Human Factors, Abstract Book, 2012, 29-30.

5. Westerman R, Darby DG, Maruff P, Collie A. Computer-assisted cognitive function assessment of pilots. ADF Health 2001; 2:29-36.

6. Thompson WT. Neuropsychological evaluation of aviators: need for aviator-specific norms? United States Air Force School of Aerospace Medicine Report 2004; 20050613 015:1-11.

7. Roe RA, Hermans PH. Psychological factors in cockpit crew selection: In Bor R, Hubbard T (editors). Aviation mental health: Psychological implications for air transportation. Surrey: Ashgate Publishing Company, 2013, 161-193.

8. Kay GG. Aviation neuropsychology: In Kennedy CH, Kay GG (editors). Aeromedical Psychology. Surrey: Ashgate Publishing, 2013, 239-268.

9. Lezak M. Neurological Assessment. Third ed. New York: Oxford University Press, 1995; 17-44.

10. Soysal AS, Arhan E, Akturk A, Can H. Hand dominance and factors determining hand dominance. Turkish Journal of Pediatric Disease 2007; 1:60-68. (Turkish)
Informed Consent: Written consent was obtained from the participants.

Peer-review: Externally peer-reviewed.

Conflict of Interest: Authors declared no conflict of interest.

Financial Disclosure: Authors declared no financial support.

11. Weintraub SM. Principles of Behavioral and Cognitive Neurology: In Mesulam MM (editor). Neuropsychological Assessment of Mental State. Second ed. Oxford: Oxford University Press, 2000, 121-173

12. Zillmer EA, Spiers MV, Culbertson WC. Principles of Clinical Neuropsychology. Second ed., Belmont: Thomson Wadsworth, 2008; 224-265.

13. MacPherson SE, Turner MS, Bozzali M, Cipolotti L, Shallicea T. Frontal subregions mediating Elevator Counting task performance. Neuropsychologia 2010; 48:3679-3682. [CrossRef]

14. Baddeley A. Working memory. Science 1992; 255:556-559. [CrossRef]

15. Cummings JL. Neuropsychiatry and Behavioral Neurology: In Kaplan HI, Sadock BJ (editors). Comprehensive Textbook of Psychiatry. Sixth Ed. Baltimore: Williams and Wilkins, 1995.

16. Jeffrey L, Cummings MD. Neuropsychiatry and Behavioral Neurology: In Kaplan HI, Sadock BJ (editors). Comprehensive Textbook of Psychiatry. Sixth Ed. Baltimore: Williams and Wilkins, 1995.

17. Rey A. L'examen psychologique dans les cas d'encéphalopathie traumatique. Archives de Psychologie 1941; 28:286-340.

18. Meyers JE, Meyers KR. Rey complex figure test under four different administration procedures. Clin Neuropsychol 1995; 9:63-67. [CrossRef]

19. Waber DP, Holmes JM. Assessing children's memory productions of the Rey-Osterrieth complex figure. J Clin Exp Neuropsychol 1986; 8:563-580. [CrossRef]

20. Brickenkamp R. Aufmerksamkeits-Belastungs-TestHandanweisung d-2 (Attention capacity test manual d-2). Oxford, England: C. J. Hogrefe, 1962. 
21. Toker MZ. Standardization of the $\mathrm{d} 2$ attention test for middle school students in Turkey. Specialization thesis, Bosphorus University, Istanbul, 1988. (Turkish)

22. Brickenkamp R, Zillmer E. d2 Test of Attention. Cambridge: Hogrefe Publishing, 1998, 11-30.

23. Caglar E, Koruc Z. Reliability and validity of $\mathrm{d} 2$ test of attention for athletes. Hacettepe Journal of Sport Sciences 2006; 17:58-80. (Turkish)

24. Gronwall DM, Sampson H. The psychological effects of concussion. Oxford, England: Auckland U Press, 1974.

25. Tombaugh TN. A comprehensive review of the Paced Auditory Serial Addition Test (PASAT). Arch Clin Neuropsychol 2006; 21:53-76. [CrossRef]

26. Brooks JB, Giraud VO, Saleh YJ, Rodrigues SJ, Daia LA, Fragoso YD. Paced auditory serial addition test (PASAT): a very difficult test even for individuals with high intellectual capability. Arq Neuropsiquiatr 2011; 69:482-484. [CrossRef]

27. Roman DD, Edwall GE, Buchanan RJ, Patton JH. Extended norms for he paced auditory serial addition task. Clin Neuropsychol 1991; 5:33-40. [CrossRef]

28. Tombaugh TN. Trail Making Test A and B: normatif data stratified by age and education. Arch Clin Neuropsychol 2004; 19:203-214. [CrossRef]

29. Arbuthnott K, Frank J. Trail making test, part B as a measure of executive control: validation using a set-switching paradigm. J Clin Exp Neuropsychol 2000; 22:518-528. [CrossRef]

30. Cangoz B, Karakoc E, Selekler K. Standardization study of "Trail Making Test" for Turkish adults and elderly people (ages 50 and over). Turk Geriatri Derg 2007; 10:73-82. (Turkish)

31. Beck LH, Bransome ED Jr, Mirsky AF, Rosvold HE, Sarason I. A continuous performance test of brain damage. J Consult Psychol. 1956; 20:343-350. [CrossRef]

32. Bora E, Vahip S, Akdeniz F. Nature and importance of cognitive symptoms in bipolar disorder. Turk Psikiyatri Derg 2008; 19:8193. (Turkish)

33. Robertson TH, Ward T, Ridgeway V, Nimmo-Smith I. The Test of Everyday Attention (TEA). Bury St. Edmunds, UK: Thames Valley Test Company, 1994, 197-221.
34. Nys GMS, van Zandvoort MJ, van der Worp HB, Kappelle LJ, de Haan EH. Neuropsychological and neuroanatomical correlates of perseverative responses in subacute stroke. Brain 2006; 129:2148-2157. [CrossRef]

35. Fozard JL, Vercruyssen M, Reynolds SL, Hancock PA, Quilter RE. Age differences and changes in reaction time: the Baltimore longitudinal study of aging. J Gerontol 1994; 49:179-189. [CrossRef]

36. Taheri M, Arabameri E. The effect of sleep deprivation on choice reaction time and anaerobic power of college student athletes. Asian J Sports Med 2012; 3:15-20. [CrossRef]

37. Zalonis I, Christidi F, Bonakis A, Kararizou E, Triantafyllou NI, Paraskevas G, Kapaki E, Vasilopoulos D. The stroop effect in Greek healthy population: normative data for the stroop neuropsychological screening test. Arch Clin Neuropsychol 2009; 24:81-88. [CrossRef]

38. Karakas S, Erdogan Bakar E, Dogutepe Dincer E. The BILNOT Battery, Adult Manual: Studies on Research and Development of Neuropsychological Tests for Adults. Ankara: Nobel Medicine Bookstores, 2013, 16-465. (Turkish).

39. MacLeod CM. Half a century of research on the stroop effect: an integrative review. Psychol Bull 1991; 109:163-203. [CrossRef]

40. Benton AL, Sivan AB, Hamsher KdeS, Varney NR, Spreen $O$. Contributions to Neuropsychological Assessment: A Clinical Manual. Second ed., New York: Oxford University Press, 1994, 53-64.

41. Sahin A. Examination of Factor Structure of Intelligence Test and Neuropsychological Tests. Turkish Journal of Clinical Psychiatry 2002; 5:160-168. (Turkish)

42. Turkes N, Can H, Kurt M, Dikec BE. A Study to Determine the Norms for the Trail Making Test For the Age Range of 20-49 in Turkey. Turk Psikiyatri Derg 2015; 26:189-196.

43. King RE, Carretta TR, Retzlaff P, Barto E, Ree MJ, Teachout MS. Standard cognitive psychological tests predict military pilot training outcomes. Aviation Psychology and Applied Human Factors 2013; 3:28-38. [CrossRef]

44. Ozdemir B, Soysal AS. A different perspective on life: my left hand. Journal for Continuous Education 2004; 13:131-133. (Turkish) 